\title{
Analisis Termodinamika Siklus Pembangkit Listrik Tenaga Uap Kapasitas 1500 kW
}

\author{
Ochtafian Wahyu Irawan ${ }^{1, a)}$, Lutvin Susdiawan Pratama ${ }^{2, b)}$, Chairil Insani, ${ }^{3, c)}$ \\ 1,2,3Program Studi Teknik Mesin ITI, \\ Jl. Raya Puspiptek Serpong, Tangerang Selatan-Banten, Indonesia, 15320 \\ a) z.ochtafian@gmail.com, ${ }^{\text {b) }}$ lutvinsp@gmail.com, ${ }^{\text {c) }}$ chairilinsani1999@gmail.com
}

\begin{abstract}
Abstrak
Pembangkit Listrik digunakan untuk membangkitkan listrik dari berbagai sumber energi seperti pembangkit listrik tenaga uap (PLTU). PLTU ini memiliki kapasitas $1500 \mathrm{~kW}$ dengan data data yang telah diperoleh tekanan dan temperatur berdasarkan tabel properties of saturated water (liquid-vapor) temperature maka dapat dilakukan perhitungan kualitas campuran pada kondensor dan efisiensi termal pada suatu siklus pembangkit listrik tersebut. Uap jenuh memasuki turbin pada siklus Rankine ideal pada tekanan 20 bar dan mengalami ekspansi pada turbin sampai pada tekanan kondensor 2,5 bar. Dalam penelitian ini dilakukan perhitungan efisiensi termal siklus pembangkit listrik tenaga uap tersebut, kemudian setelah dilakukan perhitungan didapatkan hasil efisiensi termal siklus tersebut adalah 19,3\%. Efisiensi termal dapat ditingkatkan dengan melakukan penurunan suhu dan tekanan pada kondensor, meningkatkan tekanan pada boiler, dan meningkatkan suhu ketika fluida kerja dalam keadaan superheated.
\end{abstract}

Kata kunci: efisiensi termal, siklus rankine ideal, turbin uap

\begin{abstract}
Power plant is used to generate electricity from various energy sources such as steam power plants (PLTU). This PLTU has a capacity of $1500 \mathrm{~kW}$ with file that has been obtained by pressure and temperature based on the properties of saturated water (liquid-vapor) temperature table, so it can be calculated the quality of the mixture on the condenser and thermal efficiency in a power plant cycle. Saturated steam enters the turbine at an ideal Rankine cycle at a pressure of $20 \mathrm{bar}$ and expands the turbine to a condenser pressure of $2.5 \mathrm{bar}$. In this research, the thermal efficiency of the steam power plant cycle will be calculated, then after the calculation is done, the result of the cycle thermal efficiency is 19,3\%. Thermal efficiency can be increased by decreasing the temperature and pressure on the condenser, increasing the pressure in the boiler, and increasing the temperature when the working fluid is superheated.
\end{abstract}

Keywords: ideal rankine cycle, steam turbine, thermal efficiency

\section{PENDAHULUAN}

A. Latar Belakang

Penggunaan listrik merupakan kebutuhan utama. Di Indonesia, pembangkit listrik umumnya menggunakan tenaga uap. Pembangkit listrik tenaga uap (PLTU) merupakan suatu pembangkit listrik dimana energi listrik dihasilkan oleh generator yang diputar oleh turbin uap yang memanfaatkan tekanan uap hasil penguapan air yang dipanaskan oleh bahan bakar di dalam ruang bakar (boiler). Salah satu komponen penting dalam PLTU adalah turbin uap. Turbin digunakan untuk memutar generator dengan cara mengubah energi termal yang terkandung dalam uap menjadi energi mekanik [1].

Energi listrik merupakan suatu faktor penting dalam proses perkembangan pembangunan dalam suatu negara. Di Indonesia perkembangan dapat dilihat berdasarkan semakin meningkatnya jumlah penduduk beserta berkembangnya kegiatan dalam sektor industri. Dengan demikian mengakibatkan kebutuhan energi listrik yang bertambah. Penggunaan pembangkit listrik dalam sektor perindustrian diharuskan dapat lebih efisien dalam pengoperasiannya. Pembangkit listrik tenaga uap (PLTU) merupakan salah satu jenis pembangkit listrik di Indonesia dengan fluida kerja berupa air. Pembangkit Listrik merupakan suatu alat yang digunakan untuk membangkitkan listrik dari berbagai sumber energi salah satunya adalah pembangkit listrik tenaga uap (PLTU). Salah satu unit pembangkit listrik tenaga uap ini berada di pulau Kalimantan Indonesia. Unit tersebut dimiliki oleh salah satu perusahaan di pulau tersebut. Pertama kali pada tahun 2003 dengan kapasitas $1500 \mathrm{~kW}$, pengoperasiannya digerakan oleh penggerak turbin uap yang memanfaatkan uap panas (steam) dari hasil pemanasan air di dalam boiler. Aliran uap panas tersebut digunakan untuk menggerakan sudu-sudu turbin sehingga menghasilkan energi mekanis, dimana energi mekanis tersebut digunakan untuk menggerakan generator yang terhubung langsung dengan turbin sehingga menghasilkan energi listrik. 
Suatu sistim turbin uap terdiri atas beberapa komponen utama yaitu boiler, turbin uap, kondensor, dan pompa. Generator yang dihubungkan ke turbin dimana untuk memutar turbin diperlukan energi kinetik dari uap panas atau kering. Dalam PLTU, energi primer yang dikonversikan menjadi energi listrik adalah bahan bakar. Bahan bakar yang digunakan dapat berupa batubara (padat), minyak (cair), atau gas. Ada kalanya PLTU menggunakan kombinasi beberapa macam bahan bakar. Konversi energi tingkat pertama yang berlangsung dalam PLTU adalah konversi energi primer menjadi energi panas (kalor). Hal ini dilakukan dalam ruang bakar dari ketel uap PLTU. Energi panas ini kemudian dipindahkan ke dalam air yang ada dalam pipa ketel untuk menghasilkan uap yang dikumpulkan dalam drum dari ketel. Uap dari drum ketel dialirkan ke turbin uap. Dalam turbin uap, energi uap dikonversikan menjadi energi mekanis penggerak generator, dan akhirnya energi mekanik dari turbin uap ini dikonversikan menjadi energi listrik oleh generator [2].

\section{B. Tujuan}

Tujuan dari penelitian ini adalah untuk membahas dan menganalisis beserta menerapkan antara teori mengenai kualitas (air dan uap), kerja yang dihasilkan turbin, kerja yang dibutuhkan pompa, dan efisiensi termal siklus pada komponen-komponen yang terinstalasi tersebut sesuai dengan perhitungan termodinamika.

Penelitian ini juga diharapkan dapat memberikan informasi mengenai pembangkit listrik tenaga uap yang bekerja berdasarkan prinsip kerja dari siklus Rankine.

\section{Rumusan Masalah}

Penelitian ini fokus pada pembangkit listrik tenaga uap, dimana akan dilakukan analisis perhitungan untuk mencari kualitas campuran, kerja turbin, kerja yang dibutuhkan pompa, dan efisiensi termal pada suatu siklus Rankine ideal tersebut sesuai dengan perhitungan termodinamika dan analisis siklus pembangkit listrik yang didapat.

\section{Batasan Masalah}

Untuk menghindari meluasnya masalah dan untuk mempermudah dalam memahami permasalahan yang akan dibahas maka diperlukan batasan masalah dalam penulisan penelitian ini yaitu sebagai berikut:

1. Pada penelitian ini hanya membahas berdasarkan data-data yang didapat pada rangkaian pembangkit listrik ini.

2. Perhitungan yang digunakan mengacu pada literatur siklus Rankine dan teori termodinamika dengan literatur yang relevan.

3. Perhitungan yang digunakan hanya dibahas mengenai kualitas campuran antara air dan uap, kerja turbin, kerja pompa, dan efisiensi termal siklus berdasarkan komponen yang digunakan.

4. Tidak membahas lebih lanjut mengenai pemanfaatan penggunaan pembangkit listrik tenaga uap tersebut.

5. Data-Data pendukung yang diperlukan diambil sesuai dengan literatur yang relevan
6. Tidak membahas lebih lanjut mengenai permasalahan cara meningkatkan efisiensi termal dan heat exchanger.

\section{LANDASAN TEORI}

\section{A. Pembangkit Listrik}

Pembangkit listrik merupakan suatu rangkaian alat yang mampu membangkitkan atau memproduksi sebuah energi listrik dengan cara mengubah suatu energi tertentu menjadi sebuah energi listrik. PLTU atau pembangkit listrik tenaga uap adalah sebuah pembangkit yang mengandalkan energi kinetik dari uap untuk menghasilkan energi listrik. Pembangkit ini mampu membangkitkan atau memproduksi energi listrik dengan cara memanfaatkan aliran uap panas (steam) dari hasil pemanasan air di dalam boiler. Kemudian aliran tersebut menggerakan sudu-sudu turbin sehingga dari gerakan tersebut menghasilkan energi mekanis. Maka dari itu energi mekanis tersebut dimanfaatkan untuk memutarkan generator sehingga menghasilkan energi listrik. Menurut Patrarijaya Consultant, dalam sebuah Pembangkit listrik tenaga uap efisiensi suatu PLTU biasanya sekitar 25\% sampai 50\% [3].

Efisiensi termal suatu pembangkit tenaga listrik adalah energi listrik yang dihasilkan dibagi jumlah bahan bakar yang dipergunakan. Dalam menghasilkan listrik, suatu Pembangkit Listrik Tenaga Uap (PLTU) membutuhkan beberapa komponen. Berikut ini adalah gambaran komponen-komponen utama dalam PLTU.

Selain itu pembangkit listrik tenaga uap juga memiliki keunggulan dan kekurangannya. Berikut ini keunggulan dan kekurangan dari pembangkit listrik tenaga uap.

Keunggulan PLTU diantaranya sebagai berikut:

1. Tidak bergantung pada alam seperti halnya PLTA sehingga dapat beroperasi sepanjang waktu selama tersedianya bahan bakar konvensional.

2. Dapat dibangun pada tempat yang memang memiliki potensi beban yang tinggi.

3. Biaya Operasional relatif lebih rendah dibanding pembangkit listrik lainnya

Kelemahan PLTU diantaranya sebagai berikut:

1. Dengan digunkannya bahan bakar konvensional, maka adanya kemungkinan PLTU akan sulit dioperasikan dimasa depan karena persedian bahan bakar konvensional yang semakin menipis.

2. Tidak mampu melayani beban puncak dengan baik karena waktu start nya yang lama.

3. Pembangkit listrik ini sangat mencemari lingkungan dibandingkan dengan pembangkit listrik lainnya.

\section{B. Siklus Rankine}

Siklus Rankine merupakan siklus umum yang sering digunakan sebagai standar untuk sebuah pembangkit listrik dengan menggunakan air sebagai fluida kerjanya. Pada siklus Rankine ini terdapat proses kompresi isentropik, penambahan panas isobarik, ekspansi isentropik, dan juga pelepasan panas isobarik.

Siklus Rankine menggambarkan pengoperasian mesin pemanas uap yang biasa ditemukan di pembangkit listrik tenaga uap, tenaga dihasilkan dengan menguapkan dan 
mengembunkan fluida kerja secara bergantian (dalam banyak kasus air, meskipun zat pendingin seperti amonia juga dapat digunakan). Ada empat proses dalam siklus Rankine, yang masing-masing mengubah keadaan fluida kerja [4].

\section{- Siklus Rankine Ideal}

Siklus Rankine adalah sebuah siklus termodinamika yang dimana mengubah panas menjadi kerja. Siklus Rankine pertama kali ditemukan oleh William John Maqcuom Rankine. Siklus Rankine ideal yang pada umumnya digunakan pada suatu pembangkit listrik tenaga uap. Pada siklus ini memiliki dua fase fluida kerja, yaitu liquid (cair) dan vapor (uap). Pada siklus ini pada umumnya fluida kerja yang duginakan adalah air. Siklus Rankine ini memiliki empat komponen, yakni:

\section{Boiler}

Boiler adalah suatu perangkat mesin yang berfungsi untuk merubah air menjadi uap. Dimana proses air agar dapat menjadi uap dapat terjadi dengan cara memanaskan air yang berada didalam boiler dengan memanfaatkan panas dari hasil aktifitas pembakaran bahan bakar tersebut. Pada umumnya boiler terbagi menjadi dua jenis, yaitu fire tube boiler (boiler pipa api) dan water tube boiler (boiler pipa air). Pada fire tube boiler biasanya digunakan untuk kapasitas steam yang relatif kecil dengan tekanan rendah hingga sedang. Proses pengapiannya terjadi didalam pipa kemudian panas yang dihasilkan dari proses pengapian tersebut dihantarkan langsung kedalam boiler yang berisi air tersebut. Boiler ditunjukkan pada Gambar 1.

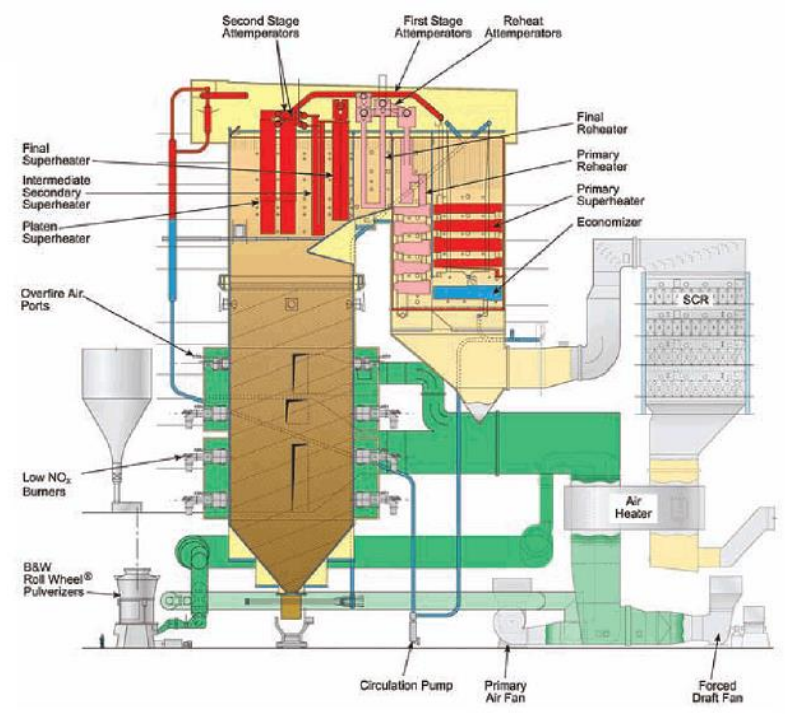

Gambar 1. Boiler

\section{Turbin Uap}

Turbin uap adalah suatu penggerak mula yang mengubah energi potensial uap menjadi energi kinetik kemudian energi kinetik tersebut diubah menjadi energi mekanis dalam bentuk putaran poros turbin dan poros tersebut terhubung dengan generator sehingga generator dapat menghasilkan energi listrik. Berikut ini adalah gambaran sebuah turbin uap. Turbin uap ditunjukkan pada Gambar 2.

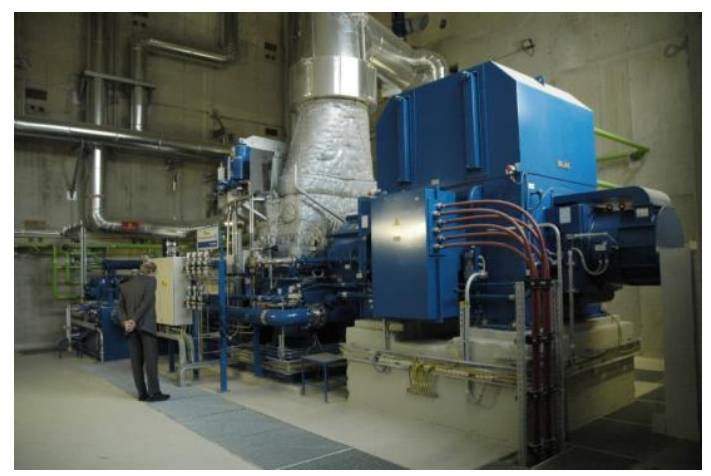

Gambar 2. Turbin Uap

\section{Kondensor}

Kondensor adalah sebuah alat yang berfungsi untuk merubah fase uap menjadi fase cair. Dimana dalam sebuah pembangkit listrik digunakan untuk merubah uap yang sudah digunakan untuk memutar poros di turbin menjadi air dengan cara dikondensasi (perubahan wujud benda dari uap menjadi air). Sistem close loop adalah suatu sistem kontrol dimana proses pemanfaatan fluida kerja tidak keluar ke lingkungan, melainkan fluida kerja tersebut hanya berproses pada rangkaian siklus saja. Kemudian setelah terjadi perubahan wujud tersebut ditampung terlebih dahulu dan kemudian akan dipompa kembali ke boiler. Dengan tekanan yang lebih rendah di kondensor maka uap dapat bergerak dengan mudah menuju kondensor. Berikut ini adalah gambar dari sebuah kondensor. Kondensor dapat dilihat pada Gambar 3 berikut ini.

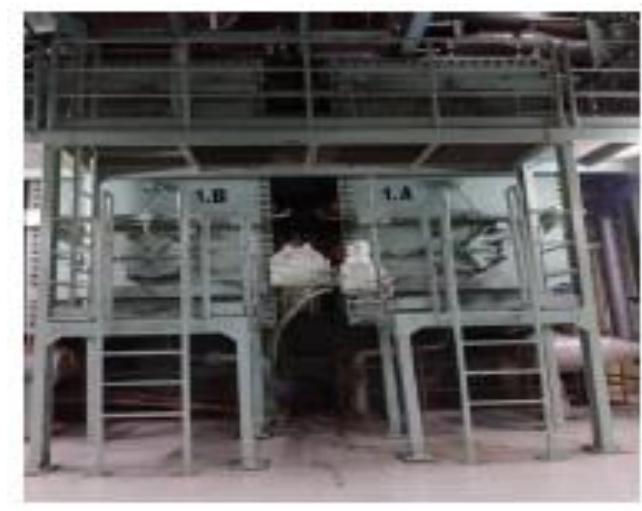

Gambar 3. Kondensor

\section{Pompa}

Pompa adalah sebuah alat yang berfungsi untuk memindahkan suatu fluida dari suatu tempat ke tempat yang lain. Selain itu juga untuk mengalirkan fluida dari tekanan rendah ke tekanan tinggi. Pada suatu pembangkit tenaga uap pompa memiliki berbagai macam jenis, salah satunya adalah boiler feed pump. Dimana pompa ini berfungsi untuk mensuplai air dalam proses pembakaran yang terjadi didalam boiler. Air tersebut merupakan hasil dari fluida kerja dari kondensor [5]. 


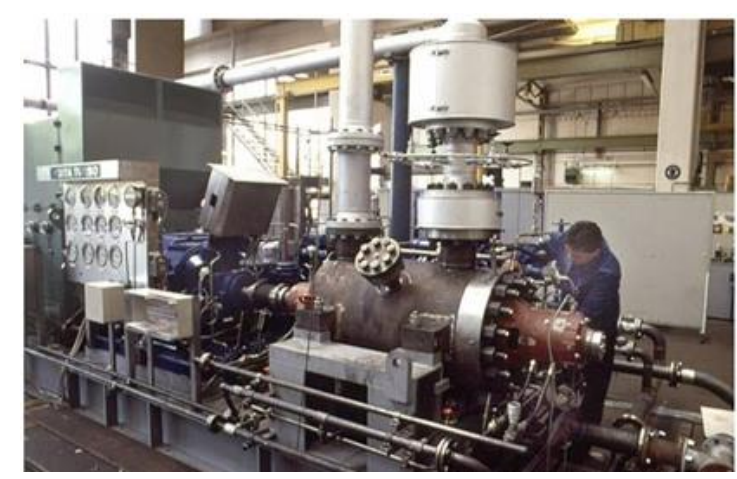

Gambar 4. Boiler feed pump

Pada Gambar 5 berikut adalah suatu siklus yang terjadi pada pembangkit listrik tenaga uap.

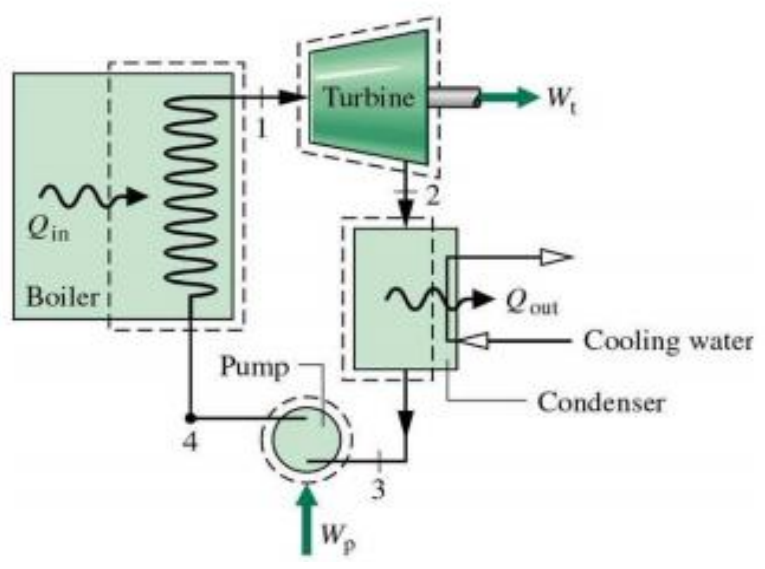

Gambar 5. Siklus pembangkit listrik tenaga uap

Gambar diagram T-S pada siklus Rankine ditunjukkan pada Gambar 6.

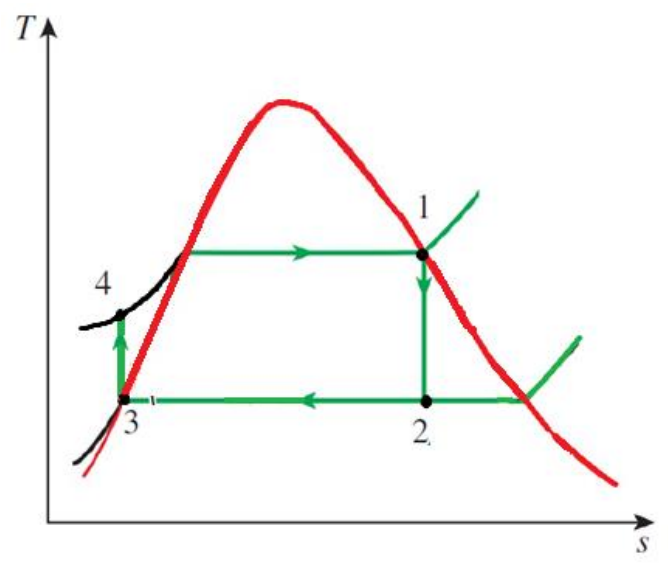

Gambar 6. Diagram t-s siklus rankine

Pada Gambar 6, terdapat empat proses pada siklus tersebut, berikut penjelasan mengenai empat proses tersebut:

Proses 1-2: Uap bertekanan dan temperatur tinggi dari boiler masuk ke turbin, terjadi proses ekspansi secara isentropik (ideal). Terjadi penurunan tekanan pada fluida kerja.

Proses 2-3: Fluida kerja keluar dari turbin dalam kondisi tekanan rendah, lalu fluida kerja masuk ke dalam kondensor dan terjadi proses kondensasi.

Proses 3-4: Fluida kerja yang berupa cair (air) memasuki pompa lalu dikompresi sehingga meningkatkan tekanan dari fluida kerja tersebut. Dan pada fase ini fluida kerja masih berwujud cair atau cair jenuh terjadi perubahan entrophy.

Proses 4-1: Fluida kerja bertekanan tinggi dari hasil kompresi pada pompa masuk kedalam boiler. Pada boiler fluida secara isobaris (tidak ada perubahan tekanan fluida selama proses) panas boiler didapat dari hasil pembakaran diluar. Pada proses ini terjadi perubahan wujud fluida dari cair menjadi campuran dan kemudian jadi uap jenuh hingga uap lanjut (superheated).

\section{Beberapa Cara Meningkatkan Efisiensi Termal}

Beberapa cara yang dapat dilakukan untuk dapat meningkatkan efisiensi pada suatu Steam Power Plants adalah sebagai berikut:

1. Menurunkan suhu dan tekanan kondensor

Penurunan suhu dan tekanan pada kondensor dapat berpengaruh terhadap kualitas dari fluida kerja tersebut. menurunkan tekanan operasi kondensor secara otomatis menurunkan suhu steam dan dengan demikian suhu panas dibuang [6].

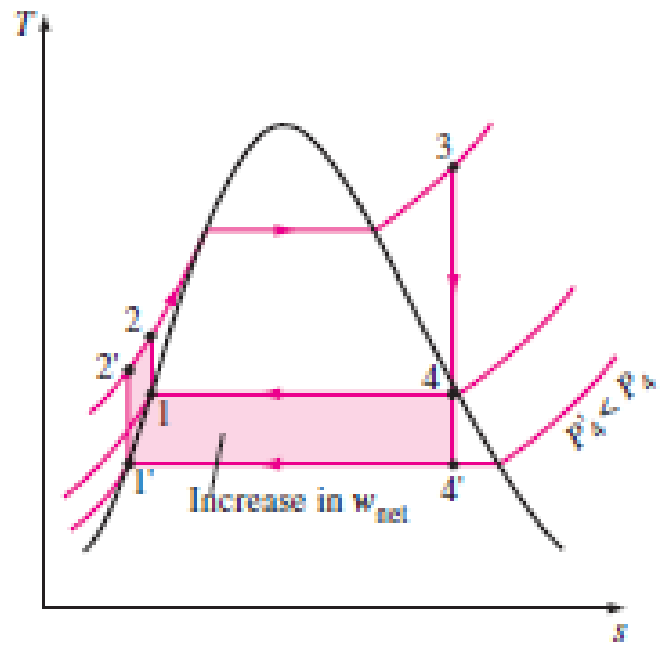

Gambar 7. Diagram t-s efek menurunkan tekanan kondensor

2. Meningkatkan suhu tekanan pada boiler

Pengaruh peningkatan tekanan boiler terhadap kinerja siklus tenaga uap untuk suhu masuk turbin tetap, siklus bergeser ke kiri dan kadar air uap di pintu keluar turbin meningkat. Namun, efek samping yang tidak diinginkan ini dapat dikoreksi dengan memanaskan kembali uap [6]. 


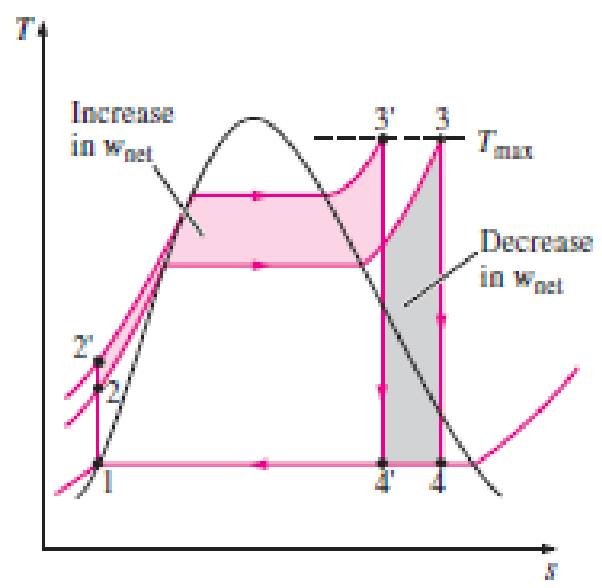

Gambar 8. Diagram t-s efek menaikan tekanan boiler

2. Meningkatkan suhu pada saat fluida kerja berada dalam keadaan superheated

kerja bersih maupun masukan panas meningkat sebagai hasil dari pemanasan berlebih pada uap ke suhu yang lebih tinggi. Efek keseluruhannya adalah peningkatan efisiensi termal, karena suhu rata-rata di mana panas ditambahkan meningkat. Superheating uap ke suhu yang lebih tinggi memiliki efek lain yang sangat diinginkan [6].

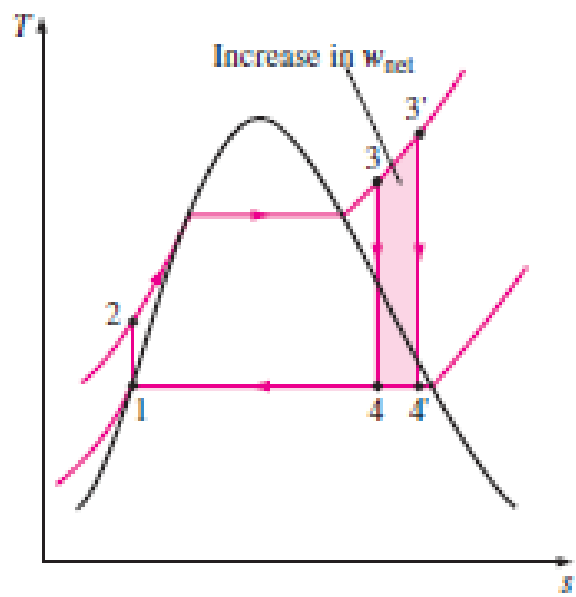

Gambar 9. Diagram t-s efek pemanasan berlebih pada ap suhu yang lebih tinggi

\section{Real Rankine Cycle}

Pada real Rankine cycle efisiensi yang dapat dicapai kurang dari efisiensi siklus Rankine yang ideal, karena tidak ada proses kompresi dan ekspansi yang isentropik. Dalam siklus Rankine yang ideal baik kompresi dalam pompa umpan boiler dan ekspansi turbin berlangsung secara isentropis (secara reversible dan adiabatis), oleh karena itu efisiensi siklus Rankine yang ideal dapat dianggap sebagai efisiensi tertinggi yang dapat dicapai. Ini karena proses pada penyelesaian ini tidak dapat dibalik sehingga menyebabkan entropi meningkat selama kompresi dalam pompa umpan boiler (proses isentropik meningkat 3-4s menjadi proses 3-4) serta selama ekspansi diturbin (proses isentropik meningkat 1-2s) untuk memproses 1-2, yang selanjutnya dapat menghasilkan peningkatan daya yang dibutuhkan oleh pompa umpan boiler dan penurunan daya yang dihasilkan oleh turbin [7].

\section{E. Reheat Rankine Cycle}

Untuk pembangkit listrik tenaga uap besar, sangat penting untuk memaksimalkan efisiensi termal dan meminimalkan konsumsi uap tertentu. Yang mendasari tujuan pemanasan ulang bukan untuk meningkatkan efisiensi siklus tetapi untuk mengurangi kelembapan kandungan uap di keluaran turbin. Namun demikian, dengan pemanasan ulang termal efisiensi siklus meningkat secara signifikan dibandingkan dengan siklus non-reheat. Pemanasan ulang paling cocok untuk unit yang bertekanan tinggi karena menghasilkan uap dengan volume spesifik yang rendah. Semakin tinggi tekanan boiler dan semakin rendah tekanan kondensor maka semakin rendah kualitas keluaran turbin yang dihasilkan. Bahkan superheat mungkin tidak cukup untuk memperbaikinya. Jika diinginkan kualitas akhir $98 \%$ pada keluaran turbin, suhu superheat harus diperpanjang hingga lebih dari $1.500^{\circ} \mathrm{F}$.

Pilihan yang lebih praktis untuk mencapai steam yang lebih kering adalah konsep reheat. Dalam sistem ini, seperti sebelumnya, uap diperluas diturbin. Sebelum pemuaian dengan sempurna terjadi, bagaimanapun, uap diekstraksi dan dipanaskan kembali untuk menambahkan entalpi, dan akhirnya dibawa keturbin tekanan rendah untuk pemuaian ketekanan kondensor. Pada gambar 2.8 diagram T-s menunjukkan pengoperasian sistem 600 psia dengan superheat $1.000^{\circ} \mathrm{F}$, dan uap pemanas ulang 1.000 ${ }^{\circ} \mathrm{F}, 100$ psia. Dalam contoh ini, uap awalnya diperluas dalam turbin bertekanan tinggi hingga 100 psia (titik 4a) sebelum dipanaskan kembali [8].

\section{F. Superheater Cycle}

Superheater adalah perangkat yang memanaskan uap yang dihasilkan oleh boiler lagi, meningkatkan energi termalnya dan mengurangi kemungkinan kondensasi di dalam mesin. Superheater meningkatkan efisiensi turbin uap, dan digunakan secara luas. Steam yang telah superheated secara logika dikenal dengan istilah superheated steam.

Steam superheated adalah steam pada suhu yang lebih tinggi dari titik didih air. Jika steam jenuh dipanaskan pada tekanan konstan, suhunya juga akan tetap konstan karena kualitas steam (misalkan kekeringan) meningkat menuju $100 \%$ steam jenuh kering. Masukan panas yang berkelanjutan kemudian akan menghasilkan uap panas berlebih. Dalam superheater pemanasan lebih lanjut pada tekanan tetap menghasilkan peningkatan suhu dan volume tertentu [9].

\section{METODE PENELITIAN/EKSPERIMEN}

Pada penelitian ini dilakukan dengan menggunakan 2 metode, yaitu menggunakan metode studi literatur, dan perhitungan secara manual.

Yang pertama pada metode studi literatur dilakukan dengan cara mencari dan mempelajari referensi dari berbagai buku literatur, jurnal, skripsi, dan website di internet yang berhubungan dengan penelitian ini. 
Kemudian metode perhitungan secara manual dilakukan dengan menggunakan rumus-rumus serta standar yang telah ada dan berlaku kemudian dihitung menggunakan alat hitung berupa Scientific Calculator.

Pelaksanaan penelitian ini mengikuti diagram alir perancangan yang ditunjukkan pada gambar 10 .

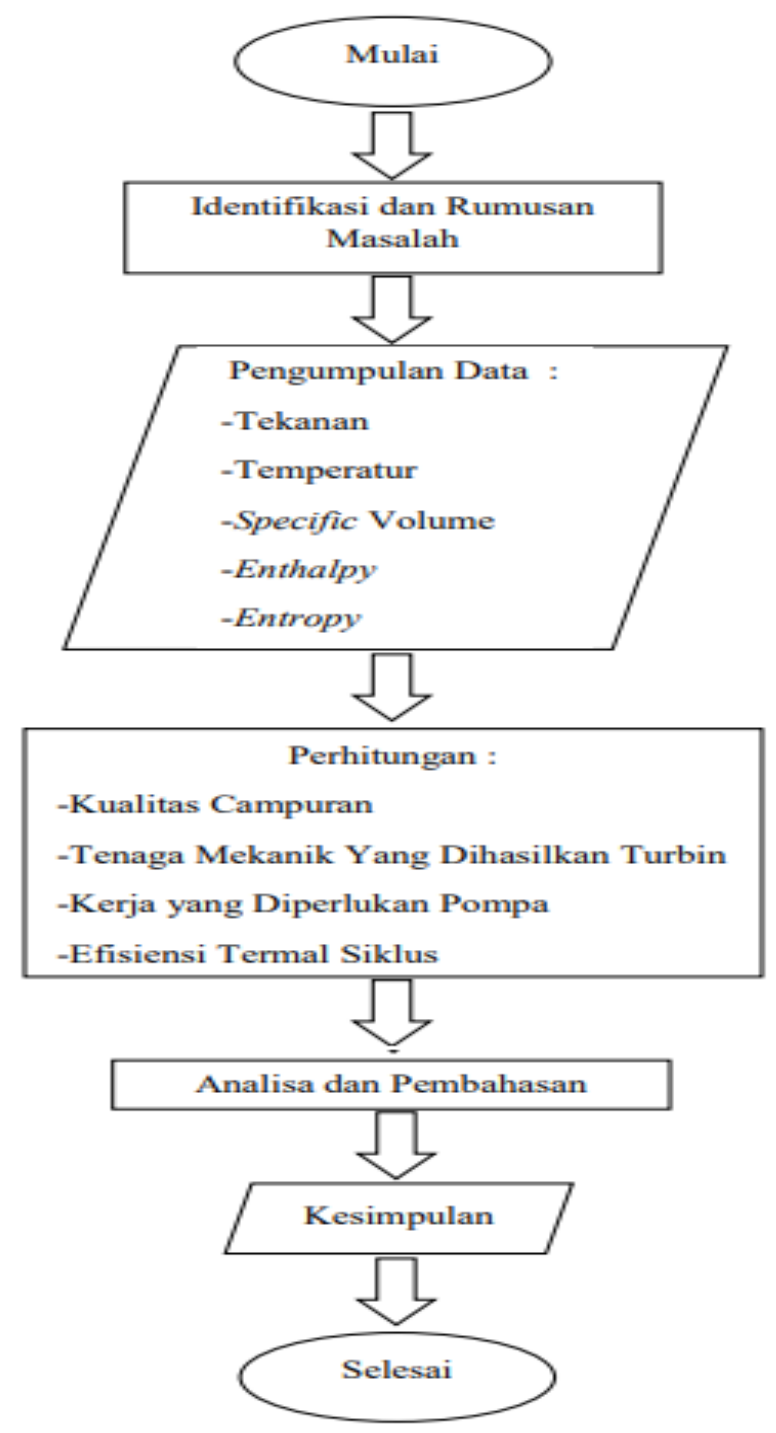

Gambar 10. Diagram alir penelitian

\section{HASIL DAN PEMBAHASAN}

Data-data spesifikasi yang didapat berdasarkan komponen yang terinstalasi dan data pendukung dari tabel Properties of Saturated Water (Liquid-Vapor): Temperature Table dan Pressure Table. Berikut ini adalah data-data yang didapatkan:

$>$ Tekanan uap jenuh memasuki turbin: 20 Bar

$>$ Temperatur uap jenuh memasuki turbin: $212^{\circ} \mathrm{C}$

$>$ Ekspansi di turbin tekanan dan temperatur: 2,5 Bar dan $127^{\circ} \mathrm{C}$

$>$ Entalphy Saturated Vapor tekanan 20 Bar: 2799,5 $\mathrm{kJ} / \mathrm{kg}$

Entrophy Saturated Vapor tekanan 20 Bar: 6.3409 $\mathrm{kJ} / \mathrm{kg} \mathrm{k}$
Entrophy Saturated Liquid tekanan 2.5 Bar: 1,6072 $\mathrm{kJ} / \mathrm{kg} \mathrm{k}$

$>$ Entrophy Saturated vapor tekanan 2,5 Bar: 7,0527 $\mathrm{kJ} / \mathrm{kg} \mathrm{k}$

$>$ Entalphy Saturated Vapor tekanan 2,5 Bar: 2716,9 $\mathrm{kJ} / \mathrm{kg}$

Dntalphy Saturated liquid tekanan 2,5 Bar: 535,37 $\mathrm{kJ} / \mathrm{kg}$

> Specific volume Saturated liquid tekanan 2,5 Bar: $1,0672 \times 10^{3} \mathrm{~m}^{3} / \mathrm{kg}$

\section{A. Kualitas Campuran}

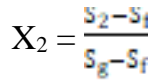

Kualitas campuran dengan simbol $\mathrm{x}$ dengan tekanan pada 20 bar dan 2,5 bar, berdasarkan tabel properties of saturated water (liquid-vapor): temperature table memiliki data data sebagai berikut:

Tekanan pada 20 Bar:

$$
\begin{aligned}
& \mathrm{h}_{1}=\mathrm{h}_{\mathrm{g}(20 \text { Bar })}=2799,5 \mathrm{~kJ} / \mathrm{kg} \\
& \mathrm{S}_{1}=\mathrm{S}_{\mathrm{g}(20 \text { Bar })}=6.3409 \mathrm{~kJ} / \mathrm{kg} \mathrm{k}
\end{aligned}
$$

Tekanan pada 2,5 Bar:

$\mathrm{S}_{\mathrm{f}}=1,6072 \mathrm{~kJ} / \mathrm{kg} \mathrm{k}$

$\mathrm{S}_{\mathrm{g}}=7,0527 \mathrm{~kJ} / \mathrm{kg} \mathrm{k}$

$\mathrm{S}_{2}=\mathrm{S}_{1}=6.3409 \mathrm{~kJ} / \mathrm{kg} \mathrm{k}$

Jadi kualitas campuran, $X_{2}=\frac{S_{2}-S_{f}}{S_{g}-S_{f}}$

$$
\begin{aligned}
& \mathrm{X}_{2}=\frac{6,3409 \mathrm{kj} / \mathrm{kg} \mathrm{k}-1,6072 \mathrm{kj} / \mathrm{kg} \mathrm{k}}{7,0527 \mathrm{kj} / \mathrm{kg} \mathrm{k}-1,6072 \mathrm{kj} / \mathrm{kg} \mathrm{k}} \\
& X_{2}=\frac{4,7337 \mathrm{kj} / \mathrm{kg} \mathrm{k}}{5,4455 \mathrm{kj} / \mathrm{kg} \mathrm{k}} \\
& X_{2}=0,8693
\end{aligned}
$$

Sehingga: Uap $=86,93 \%$

$$
\text { Air }=13,07 \%
$$

\section{B. Tenaga Mekanik Yang Dihasilkan Turbin}

$\mathrm{Wt}=\mathrm{m}\left(\mathrm{h}_{1}-\mathrm{h}_{2}\right)$

$\frac{\mathrm{Wt}}{\mathrm{m}}=\mathrm{h}_{1}-\mathrm{h}_{2}$

Dimana: $\mathrm{h}_{2}=\mathrm{h}_{\mathrm{f}}+\mathrm{X}_{2}\left(\mathrm{~h}_{\mathrm{g}}-\mathrm{h}_{\mathrm{f}}\right)$

$$
\begin{aligned}
& \mathrm{h}_{2}=\mathrm{h}_{\mathrm{f}+} 0,8693\left(\mathrm{~h}_{\mathrm{g}}-\mathrm{h}_{\mathrm{f}}\right) \\
& \mathrm{h}_{2}=\mathrm{h}_{\mathrm{f}+} 0,8693\left(\mathrm{~h}_{\mathrm{fg}}\right)
\end{aligned}
$$

Berdasarkan tabel properties of saturated water (liquid-vapor): temperature table. Pada tekanan 2,5 Bar didapat $\mathrm{h}_{\mathrm{g}}=2716,9 \mathrm{~kJ} / \mathrm{kg}$ dan $\mathrm{h}_{\mathrm{f}}=535,37 \mathrm{~kJ} / \mathrm{kg}$ sehingga $\mathrm{h}_{\mathrm{fg}}=2181,5 \mathrm{~kJ} / \mathrm{kg}$, dengan demikian

$$
\begin{aligned}
\mathrm{h}_{2} & =\mathrm{h}_{\mathrm{f}+} 0,8693\left(\mathrm{~h}_{\mathrm{fg}}\right) \\
& =535,37 \mathrm{~kJ} / \mathrm{kg}+0,8693(2181,5 \mathrm{~kJ} / \mathrm{kg}) \\
& =2431,75 \mathrm{~kJ} / \mathrm{kg}
\end{aligned}
$$

Sehingga: $\frac{\mathrm{Wt}}{\mathrm{m}}=\mathrm{h}_{1}-\mathrm{h}_{2}$ 
$\frac{\mathrm{Wt}}{\mathrm{m}}=2799,5 \mathrm{~kJ} / \mathrm{kg}-2431,75 \mathrm{~kJ} / \mathrm{kg}$

$\frac{\mathrm{Wt}}{\mathrm{m}}=367,75 \mathrm{~kJ} / \mathrm{kg}$

\section{Kerja Yang Diperlukan Pompa}

Pompa pada dasarnya adalah volume kontrol yang secara adiabatis meningkatkan tekanan cairan. Kerja yang diperlukan pompa dapat dihitung menggunakan persamaan berikut ini:

$\mathrm{W}_{\mathrm{p}}=\mathrm{m}\left(\mathrm{h}_{4}-\mathrm{h}_{3}\right)$
$\frac{w_{\mathrm{p}}}{\mathrm{m}}=\left(\mathrm{h}_{4}-\mathrm{h}_{3}\right)$

Dimana: $\mathrm{h}_{3}=\mathrm{h}_{\mathrm{f}(2,5 \text { Bar })}=535,37 \mathrm{kj} / \mathrm{kg}$

$\mathrm{h}_{4}=\frac{\mathrm{Wp}}{\mathrm{m}}+\mathrm{h}_{3}$

$\mathrm{h}_{4}=\mathrm{V}_{3(2,5 \text { Bar })}\left(\mathrm{P}_{4}-\mathrm{P}_{3}\right)+\mathrm{h}_{3}$

$\mathrm{V}_{3(2,5 \text { Bar })}=\mathrm{V}_{\mathrm{f}(2,5 \text { Bar })}=1,0672 \times 10^{3} \mathrm{~m}^{3} / \mathrm{kg}$

Jadi:

$\mathrm{h}_{4}=1,0672 \times 10^{3} \mathrm{~m}^{3} / \mathrm{kg}(20-2,5) \mathrm{Bar}+535,37 \mathrm{kj} / \mathrm{kg}$

$\mathrm{h}_{4}=18,68 \times 10^{3} \mathrm{~m}^{3} / \mathrm{kg} \operatorname{Bar}\left(\frac{\mathrm{kj}}{10^{3}}\right)\left(\frac{10^{5} \mathrm{Nm}}{\operatorname{Bar}}\right)+535,37 \mathrm{kj} / \mathrm{kg}$

$\mathrm{h}_{4}=1,868 \mathrm{kj} / \mathrm{kg}+535,37 \mathrm{kj} / \mathrm{kg}$

$\mathrm{h}_{4}=537,24 \mathrm{kj} / \mathrm{kg}$

Sehingga: $\frac{\mathrm{Wp}}{\mathrm{m}}=\left(\mathrm{h}_{4}-\mathrm{h}_{3}\right)$

$\frac{W_{p}}{m}=(537,24 \mathrm{kj} / \mathrm{kg}-535,37 \mathrm{kj} / \mathrm{kg})$

$\frac{W_{p}^{m}}{m}=1,87 \mathrm{kj} / \mathrm{kg}$

\section{Efisiensi Termal Siklus}

Untuk dapat menentukan efisiensi termal pada siklus tersebut dapat menggunakan persamaan sebagai berikut:

$$
\begin{aligned}
& \eta=\frac{\frac{W t}{m}-\frac{W p}{m}}{\frac{Q i n}{m}} \\
& \text { Dimana: } \frac{Q i n}{m}=h_{2}-h_{3} \\
& \frac{\text { Qin }}{m}=2431,75 \mathrm{kj} / \mathrm{kg}-535,37 \mathrm{kj} / \mathrm{kg} \\
& \frac{\text { Qin }}{\mathrm{m}}=1896,38 \mathrm{kj} / \mathrm{kg}
\end{aligned}
$$

Sehingga: $\eta=\frac{\frac{w t}{m}-\frac{w p}{m}}{\frac{Q i n}{m}}$

$$
\begin{aligned}
& \eta=\frac{367,75 \mathrm{kj} \mathrm{kg}-1,87 \mathrm{kj} / \mathrm{kg}}{1896,38 \mathrm{kj} / \mathrm{kg}} \\
& \eta=0,193 \\
& \eta=19,3 \%
\end{aligned}
$$

E. Efisiensi Termal Siklus Pada Turbin $89 \%$ dan Pompa $90 \%$

$>$ ๆTurbin $=\frac{\mathrm{h}_{1}-\mathrm{h}_{2}}{\mathrm{~h}_{1}-\mathrm{h}_{2}}$

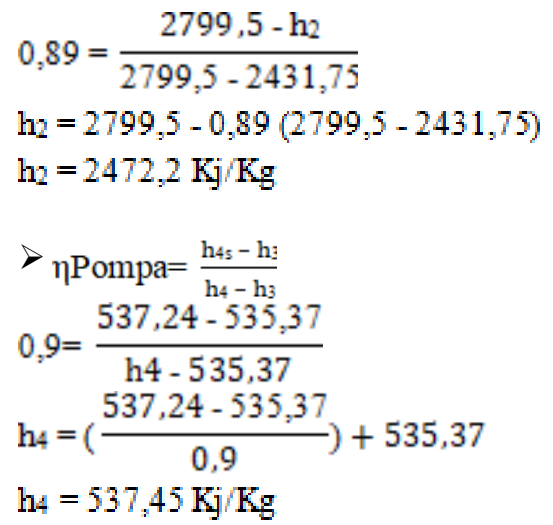

Untuk dapat menentukan efisiensi termal pada siklus tersebut dapat menggunakan persamaan sebagai berikut:

$$
\begin{aligned}
\eta_{1} & =\frac{\left(h_{1}-h_{2}\right)-\left(h_{4}-h_{i}\right)}{\left(h_{1}-h_{4}\right)} \\
\eta & =\frac{(2799,5-2472,2)-(537,45-535,37)}{(2799,5-537,45)} \\
\eta & =0,1438=14,38 \%
\end{aligned}
$$

Jadi artinya hanya 14,38 \% energi yang digunakan boiler untuk menghasilkan tenaga.

\section{F. Menurunkan Tekanan dan Suhu Kondensor}

Kualitas campuran :

Tekanan pada 20 Bar:

$$
\begin{aligned}
& \mathrm{h}_{1}=\mathrm{h}_{\mathrm{g}(20 \mathrm{Bar})}=2799,5 \mathrm{kj} / \mathrm{kg} \\
& \mathrm{S}_{1}=\mathrm{S}_{\mathrm{g}(20 \text { Bar })}=6.3409 \mathrm{kj} / \mathrm{kg} \mathrm{K}
\end{aligned}
$$

Tekanan pada 1 Bar:

$$
\mathrm{S}_{\mathrm{f}}=1,3026 \mathrm{kj} / \mathrm{kg} \mathrm{k}
$$$$
\mathrm{S}_{\mathrm{g}}=7,3594 \mathrm{kj} / \mathrm{kg} \mathrm{k}
$$$$
\mathrm{S}_{2}=\mathrm{S}_{1}=6.3409 \mathrm{kj} / \mathrm{kg} \mathrm{k}
$$

Jadi kualitas campuran, $X_{2}=\frac{S_{2}-S_{f}}{S_{g}-S_{f}}$

$X_{2}=\frac{6,3409 \mathrm{kj} k \mathrm{~kg}-1,3026 \mathrm{kj} \mathrm{kgk}}{7,3594 \mathrm{kj} \mathrm{kgk}-1,3026 \mathrm{kj} \mathrm{kgk}}$

$X_{2}=\frac{5,0383 \mathrm{kj} \mathrm{kgk}}{6,0568 \mathrm{kj} \mathrm{kgk}}$

$\mathrm{X}_{2}=0,8318$

Sehingga: Uap $=83,18 \%$

$$
\text { Air }=16,82 \%
$$

Tenaga mekanik yang dihasilkan turbin:

$$
\begin{aligned}
& \mathrm{Wt}=\mathrm{m}\left(\mathrm{h}_{1}-\mathrm{h}_{2}\right) \\
& \frac{\mathrm{Wt}}{\mathrm{m}}=\mathrm{h}_{1}-\mathrm{h}_{2} \\
& \text { Dimana: } \mathrm{h}_{2}=\mathrm{h}_{\mathrm{f}}+\mathrm{X}_{2}\left(\mathrm{~h}_{\mathrm{g}}-\mathrm{h}_{\mathrm{f}}\right) \\
& \mathrm{h}_{2}=\mathrm{h}_{\mathrm{f}}+0,8318\left(\mathrm{~h}_{\mathrm{g}}-\mathrm{h}_{\mathrm{f}}\right) \\
& \mathrm{h}_{2}=\mathrm{h}_{\mathrm{f}}+0,8318\left(\mathrm{~h}_{\mathrm{fg}}\right)
\end{aligned}
$$

Berdasarkan tabel properties of saturated water (liquid-vapor): pressure table, tekanan 1 Bar didapat $\mathrm{h}_{\mathrm{g}}=$ 
$2675,5 \mathrm{kj} / \mathrm{kg}$ dan $\mathrm{h}_{\mathrm{f}}=417,46 \mathrm{kj} / \mathrm{kg}$ sehingga $\mathrm{h}_{\mathrm{fg}}=2258$ $\mathrm{kj} / \mathrm{kg}$

Jadi: $\mathrm{h}_{2}=\mathrm{h}_{\mathrm{f}+} 0,8318\left(\mathrm{~h}_{\mathrm{fg}}\right)$

$$
\begin{aligned}
& =417,46 \mathrm{kj} / \mathrm{kg}+0,8318(2258 \mathrm{kj} / \mathrm{kg}) \\
& =2295,66 \mathrm{kj} / \mathrm{kg}
\end{aligned}
$$

Sehingga: $\frac{\mathrm{Wt}}{\mathrm{m}}=\mathrm{h}_{1}-\mathrm{h}_{2}$

$\frac{W \mathrm{t}}{\mathrm{m}}=2799,5 \mathrm{kj} / \mathrm{kg}-2295,66 \mathrm{kj} / \mathrm{kg}$

$m_{W t}$

$\frac{W \mathrm{t}}{\mathrm{m}}=503,84 \mathrm{kj} / \mathrm{kg}$

Kerja yang diperlukan pompa :

$\mathrm{W}_{\mathrm{p}}=\mathrm{m}\left(\mathrm{h}_{4}-\mathrm{h}_{3}\right)$

$\frac{W \mathrm{p}}{\mathrm{m}}=\left(\mathrm{h}_{4}-\mathrm{h}_{3}\right)$

Dimana: $\mathrm{h}_{3}=\mathrm{h}_{\mathrm{f}(1 \mathrm{Bar})}=417,46 \mathrm{kj} / \mathrm{kg}$

$\mathrm{h}_{4}=\frac{\mathrm{Wp}}{\mathrm{m}}+\mathrm{h}_{3}$

$\mathrm{h}_{4}=\mathrm{V}_{3(1 \mathrm{Bar})}\left(\mathrm{P}_{4}-\mathrm{P}_{3}\right)+\mathrm{h}_{3}$

$\mathrm{V}_{3(1 \mathrm{Bar})}=\mathrm{V}_{\mathrm{f}(1 \mathrm{Bar})}=1,0432 \times 10^{3} \mathrm{~m}^{3} / \mathrm{kg}$

Jadi: $\mathrm{h}_{4}=1,0432 \times 10^{3} \mathrm{~m}^{3} / \mathrm{kg}(20-1) \mathrm{Bar}+417,46 \mathrm{kj} / \mathrm{kg}$

$\mathrm{h}_{4}=19,82 \times 10^{3} \mathrm{~m}^{3} / \mathrm{kg} \operatorname{Bar}\left(\frac{\mathrm{kj}}{10^{3}}\right)\left(\frac{10^{5} \mathrm{Nm}}{\operatorname{Bar}}\right)+417,46 \mathrm{kj} / \mathrm{kg}$

$\mathrm{h}_{4}=1,982 \mathrm{kj} / \mathrm{kg}+417,46 \mathrm{kj} / \mathrm{kg}$

$\mathrm{h}_{4}=419,44 \mathrm{kj} / \mathrm{kg}$

Sehingga: $\frac{\mathrm{Wp}}{\mathrm{m}}=\left(\mathrm{h}_{4}-\mathrm{h}_{3}\right)$

$\frac{W p}{m}=(419,44 \mathrm{kj} / \mathrm{kg}-417,46 \mathrm{kj} / \mathrm{kg})$

$\frac{\mathrm{Wp}}{\mathrm{m}}=1,98 \mathrm{kj} / \mathrm{kg}$

Efisiensi termal siklus

$\eta=\frac{\frac{W_{t}}{m}-\frac{W p}{m}}{\underline{\mathrm{Qin}}}$

Dimana: $\frac{\text { Qin }}{\mathrm{m}}=\mathrm{h}_{2}-\mathrm{h}_{3}$

$\frac{\text { Qin }}{m}=2295,66 \mathrm{kj} / \mathrm{kg}-417,46 \mathrm{kj} / \mathrm{kg}$

$\mathrm{m}$

$\frac{\mathrm{Qin}}{\mathrm{m}}=1878,2 \mathrm{kj} / \mathrm{kg}$

Sehingga: $\eta=\frac{\frac{w t}{m}-\frac{w p}{m}}{\underline{\text { in }}}$

$\eta=\frac{503,84 \mathrm{kj} / \mathrm{kg}-1,98 \mathrm{mj} / \mathrm{kg}}{1878,2 \mathrm{kj} / \mathrm{kg}}$

$\eta=0,2672$

$\eta=26,72 \%$

Jadi artinya hanya 26,72 \% energi yang digunakan boiler untuk menghasilkan tenaga.

\section{G. Menaikan Suhu dan Tekanan Boiler}

Kualitas campuran :
Tekanan pada 25 Bar:

$$
\begin{aligned}
& \mathrm{h}_{1}=\mathrm{h}_{\mathrm{g}(25 \mathrm{Bar})}=2803,1 \mathrm{kj} / \mathrm{kg} \\
& \mathrm{S}_{1}=\mathrm{S}_{\mathrm{g}(25 \mathrm{Bar})}=6,2575 \mathrm{kj} / \mathrm{kg} \mathrm{K} \\
& \text { Tekanan pada } 2,5 \mathrm{Bar}: \\
& \mathrm{S}_{\mathrm{f}}=1,6072 \mathrm{kj} / \mathrm{kg} \mathrm{k} \\
& \mathrm{S}_{\mathrm{g}}=7,0527 \mathrm{kj} / \mathrm{kg} \mathrm{k} \\
& \mathrm{S}_{2}=\mathrm{S}_{1}=6,2575 \mathrm{kj} / \mathrm{kg} \mathrm{k}
\end{aligned}
$$

Jadi kualitas campuran, $X_{2}=\frac{S_{2}-S_{f}}{S_{g}-S_{f}}$

$\mathrm{X}_{2}=\frac{6,2575 \mathrm{kj} \mathrm{kgk}-1,6072 \mathrm{kj} \mathrm{kgk}}{7,0527 \mathrm{kj} \mathrm{kgk}-1,6072 \mathrm{kj} \mathrm{kgk}}$

$X_{2}=\frac{4,6503 \mathrm{kj} \mathrm{kgk}}{5,4455 \mathrm{kj} \mathrm{kgk}}$

$\mathrm{X}_{2}=0,8539$

Sehingga: Uap $=85,39 \%$

$$
\text { Air }=14,61 \%
$$

Tenaga mekanik yang dihasilkan turbin:

$\mathrm{Wt}=\mathrm{m}\left(\mathrm{h}_{1}-\mathrm{h}_{2}\right)$
$\frac{\mathrm{Wt}}{\mathrm{m}}=\mathrm{h}_{1}-\mathrm{h}_{2}$

Dimana: $\mathrm{h}_{2}=\mathrm{h}_{\mathrm{f}}+\mathrm{X}_{2}\left(\mathrm{~h}_{\mathrm{g}}-\mathrm{h}_{\mathrm{f}}\right)$

$\mathrm{h}_{2}=\mathrm{h}_{\mathrm{f}+} 0,8539\left(\mathrm{~h}_{\mathrm{g}}-\mathrm{h}_{\mathrm{f}}\right)$

$\mathrm{h}_{2}=\mathrm{h}_{\mathrm{f}+} 0,8539\left(\mathrm{~h}_{\mathrm{fg}}\right)$

Berdasarkan tabel properties of saturated water (liquidvapor): pressure table, tekanan 2,5 Bar didapat $\mathrm{h}_{\mathrm{g}}=$ $2716,9 \mathrm{kj} / \mathrm{kg}$ dan $\mathrm{h}_{\mathrm{f}}=535,37 \mathrm{kj} / \mathrm{kg}$ sehingga $\mathrm{h}_{\mathrm{fg}}=2181,5$ $\mathrm{kj} / \mathrm{kg}$

Jadi: $\mathrm{h}_{2}=\mathrm{h}_{\mathrm{f}+} 0,8539\left(\mathrm{~h}_{\mathrm{fg}}\right)$

$$
\begin{aligned}
& =535,37 \mathrm{kj} / \mathrm{kg}+0,8539(2181,5 \mathrm{kj} / \mathrm{kg}) \\
& =2398,15 \mathrm{kj} / \mathrm{kg}
\end{aligned}
$$

Sehingga: $\frac{\mathrm{Wt}}{\mathrm{m}}=\mathrm{h}_{1}-\mathrm{h}_{2}$

$\frac{W \mathrm{t}}{\mathrm{m}}=2803,1 \mathrm{kj} / \mathrm{kg}-2398,15 \mathrm{kj} / \mathrm{kg}$

$\mathrm{m}_{\mathrm{Wt}}$

$\frac{\mathrm{m}}{\mathrm{m}}=367,75 \mathrm{kj} / \mathrm{kg}$

Kerja yang diperlukan pompa:

$\mathrm{W}_{\mathrm{p}}=\mathrm{m}\left(\mathrm{h}_{4}-\mathrm{h}_{3}\right)$

$\frac{W \mathrm{p}}{\mathrm{m}}=\left(\mathrm{h}_{4}-\mathrm{h}_{3}\right)$

Dimana: $h_{3}=h_{f}(2,5$ Bar $)=535,37 \mathrm{kj} / \mathrm{kg}$

$$
\begin{aligned}
& \mathrm{h}_{4}=\frac{\mathrm{Wp}}{\mathrm{m}}+\mathrm{h}_{3} \\
& \mathrm{~h}_{4}=\mathrm{V}_{3(2,5 \text { Bar) }}\left(\mathrm{P}_{4}-\mathrm{P}_{3}\right)+\mathrm{h}_{3} \\
& \mathrm{~V}_{3(2,5 \text { Bar })}=\mathrm{V}_{\mathrm{f}(2,5 \text { Bar })}=1,0672 \times 10^{3} \mathrm{~m}^{3} / \mathrm{kg}
\end{aligned}
$$

Jadi: $\mathrm{h}_{4}=1,0672 \times 10^{3} \mathrm{~m}^{3} / \mathrm{kg}(20-2,5) \mathrm{Bar}+535,37$ $\mathrm{kj} / \mathrm{kg}$ 


$$
\begin{aligned}
& \mathrm{h}_{4}=18,67 \times 10^{3} \mathrm{~m}^{3} / \mathrm{kg} \operatorname{Bar}\left(\frac{\mathrm{kj}}{10^{3}}\right)\left(\frac{10^{5} \mathrm{Nm}}{B a r}\right)+535,37 \mathrm{kj} / \mathrm{kg} \\
& \mathrm{h}_{4}=1,867 \mathrm{kj} / \mathrm{kg}+535,37 \mathrm{kj} / \mathrm{kg} \\
& \mathrm{h}_{4}=537,24 \mathrm{kj} / \mathrm{kg} \\
& \text { Sehingga: } \frac{\mathrm{Wp}}{\mathrm{m}}=\left(\mathrm{h}_{4}-\mathrm{h}_{3}\right) \\
& \frac{\mathrm{Wp}_{\mathrm{p}}}{\mathrm{m}}=(537,24 \mathrm{kj} / \mathrm{kg}-535,37 \mathrm{kj} / \mathrm{kg}) \\
& \frac{W_{\mathrm{p}}}{\mathrm{m}}=1,87 \mathrm{kj} / \mathrm{kg}
\end{aligned}
$$

Efisiensi termal siklus:

$$
\eta=\frac{\frac{w t}{m}-\frac{w p}{m}}{\frac{Q \text { in }}{m}}
$$

Dimana: $\frac{\text { Qin }}{\mathrm{m}}=\mathrm{h}_{2}-\mathrm{h}_{3}$

$$
\begin{aligned}
& \frac{\text { Qin }}{m}=2398,15 \mathrm{kj} / \mathrm{kg}-535,37 \mathrm{kj} / \mathrm{kg} \\
& \frac{\text { Qin }}{\mathrm{m}}=1862,78 \mathrm{kj} / \mathrm{kg}
\end{aligned}
$$

Sehingga: $\eta=\frac{\frac{w_{t}}{m}-\frac{w_{p}}{m}}{\underline{\text { Qin }}}$

$$
\eta=\frac{367,75 \mathrm{kj} / \mathrm{kg}-1,87 \mathrm{kj} / \mathrm{kg}}{1862,78 \mathrm{kj} / \mathrm{kg}}
$$$$
\eta=0,1964=19,64 \%
$$

Jadi artinya hanya $19,64 \%$ energi yang digunakan boiler untuk menghasilkan tenaga.

\section{H. Meningkatkan Suhu Pada Saat Fluida Kerja Berada dalam Keadaan Superheated}

Dapat diketahui pada tekanan 20 Bar dilakukan superheated dengan suhu $360^{\circ} \mathrm{C}$. Maka berdasarkan tabel Properties of Superheated Water Vapor diperoleh:

Tekanan pada 20 Bar:

$$
\begin{aligned}
& \mathrm{h}_{1(20 \text { Bar })}=3159,3 \mathrm{kj} / \mathrm{kg} \\
& \mathrm{S}_{1}=6,9917 \mathrm{kj} / \mathrm{kg} \mathrm{k}
\end{aligned}
$$

Tekanan pada 2,5 Bar:

$$
\mathrm{S}_{\mathrm{f}}=1,6072 \mathrm{kj} / \mathrm{kg} \mathrm{k}
$$$$
\mathrm{S}_{\mathrm{g}}=7,0527 \mathrm{kj} / \mathrm{kg} \mathrm{k}
$$$$
\mathrm{S}_{2}=\mathrm{S}_{1}=6,9917 \mathrm{kj} / \mathrm{kg} \mathrm{k}
$$

Untuk dapat menentukan efisiensi termal pada siklus tersebut dapat menggunakan persamaan sebagai berikut:

\begin{tabular}{|c|c|c|}
\hline Keadaan & Uap Dan Air & $\begin{array}{c}\text { Efisiensi } \\
\text { Termal Siklus }\end{array}$ \\
\hline Ideal & $86,93 \% \& 13,07 \%$ & $19,3 \%$ \\
\hline Tidak Ideal & $86,93 \% \& 13,07 \%$ & $14,38 \%$ \\
\hline $\begin{array}{l}\text { Menurunkan } \\
\text { Tekanan } \\
\text { Kondensor }\end{array}$ & $83,18 \%$ \& $16,82 \%$ & $26,72 \%$ \\
\hline $\begin{array}{c}\text { MenaikanTekanan } \\
\text { Boiler }\end{array}$ & $85,39 \% \& 14,61 \%$ & 19,64 \\
\hline $\begin{array}{l}\text { Melakukan } \\
\text { Superheated }\end{array}$ & $98,87 \% \& 1,13 \%$ & $17,74 \%$ \\
\hline
\end{tabular}

$$
\eta=\frac{\left(\mathrm{h}_{1}-\mathrm{h}_{2}\right)-\left(\mathrm{h}_{4}-\mathrm{h}_{3}\right)}{\left(\mathrm{h}_{1}-\mathrm{h}_{4}\right)}
$$

Sehingga Kualitas Campuran: $\mathrm{X}_{2}=\frac{\mathrm{S}_{2}-\mathrm{S}_{\mathrm{f}}}{\mathrm{S}_{\mathrm{g}}-\mathrm{S}_{\mathrm{f}}}$

$$
\begin{aligned}
& X_{2}=\frac{6.9917 \mathrm{kj} \mathrm{kg} \mathrm{k}-1,6072 \mathrm{kj} \mathrm{kg} \mathrm{k}}{7,0527 \mathrm{kj} \mathrm{kg} \mathrm{k}-1,6072 \mathrm{kj} \mathrm{kg} \mathrm{k}} \\
& X_{2}=\frac{5,3845 \mathrm{kj} \mathrm{kg} \mathrm{k}}{5,4455 \mathrm{kj} \mathrm{kg} \mathrm{k}} \\
& X_{2}=0,9887
\end{aligned}
$$

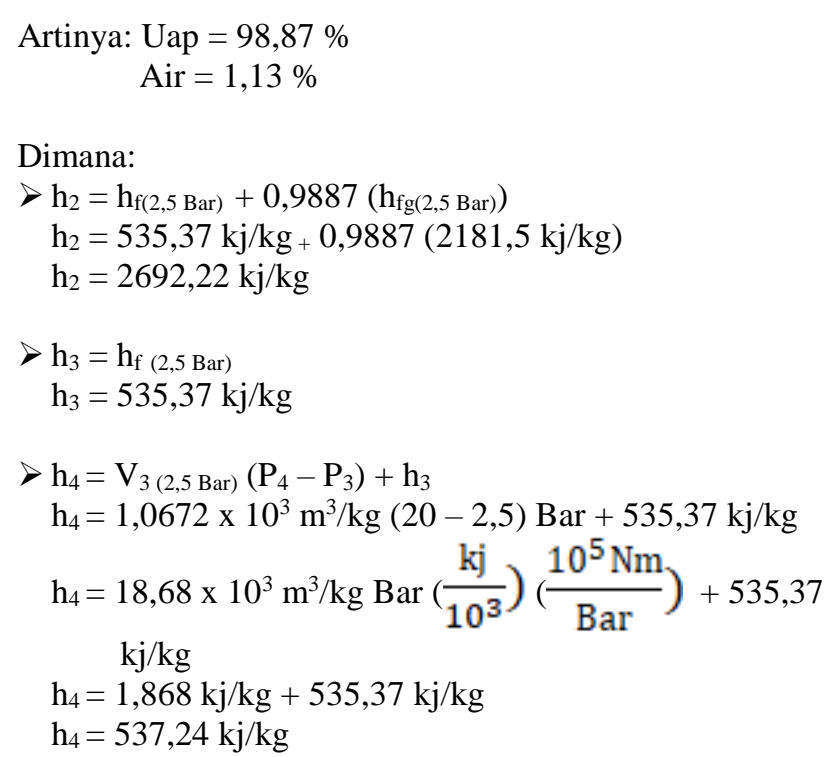

Sehingga Efisiensi Termal Siklus Ketika Dilakukan Proses Superheated menjadi:

$$
\eta=\frac{(3159,3-2692,22)-(537,24-535,37)}{(3159,3-537,24)}
$$

$\eta=0,1774=17,74 \%$

Jadi artinya hanya $17,74 \%$ energi yang digunakan boiler untuk menghasilkan tenaga.

Tabel 1. Hasil efisinsi termal siklus

\section{KESIMPULAN}

1. Berdasarkan hasil perhitungan yang didapat dari komponen yang terinstalasi pada pembangkit listrik tenaga uap ini, kualitas campuran memiliki persentase uap dengan nilai $86,93 \%$, dan untuk persentasi air dengan nilai $13,07 \%$.

2. Turbin dengan kapasitas $1580 \mathrm{~kW}$ (kilowatt), keluar dengan tekanan 2.5 Bar $127{ }^{\circ} \mathrm{C}$, uap jenuh diekspansi dalam turbin untuk dapat menghasilkan tenaga mekanik sebesar $367,75 \mathrm{Kj} / \mathrm{Kg}$.

3. Pompa yang bekerja untuk meningkatkan tekanan cairan membutuhkan kerja yang diperlukan. Sehingga kerja yang diperlukan pompa sebesar $1,87 \mathrm{Kj} / \mathrm{Kg}$.

4. Tenaga mekanik yang dihasilkan turbin dan kerja yang diperlukan pompa didapatkan sehingga efisiensi 
termal pada siklus pembangkit listrik tenaga uap ini sebesar 0,193 atau 19,3\%. 19,3\% merupakan energi yang digunakan boiler agar dapat menghasilkan tenaga.

5. Menurunkan tekanan dan suhu kondensor dapat memperbesar nilai efisiensi termal, seperti diturunkan tekanan pada 1 Bar nilai efisiensi termal menjadi $26,72 \%$

6. Meningkatkan tekanan dan suhu pada boiler juga dapat memperbesar nilai efisiensi termal, seperti menaikan tekanan pada 25 Bar nilai efisiensi termal menjadi $19,64 \%$

\section{REFERENSI}

[1] S. Satiti, Analysis of plant peformance versus variation of load on Steam turbine using cycle tempo, skripsi, Institut Teknologi Sepuluh Nopember, Surabaya, 2015.

[2] M. Hetharia and Y. J. Lewerissa, Analisis energi pada perencanaan pembangkit listrik tenaga uap (PLTU) dengan cycle tempo, Jurnal Voering, 2018, vol. 3, no. 1.

[3] Patrarijaya Consultant, Efisiensi pembangkit PLTU, 2017, Website: https://www.patrarijaya.co.id/efisiensi-pembangkit-pltu/, diakses tanggal 14 februari 2021.

[4] E. Khalil, Steam power plants chapter 4, WIT Transactions on State of the Art in Science and Engineering, 2008, vol. 42, hal. 102-103.

[5] A. Vizenza FN, Analisis unjuk kerja siklus rankine sebelum dan sesudah overhaul pada PLTU unit 2 PT. PJB u.p. Gresik, skripsi, Institut Teknologi Sepuluh Nopember, Surabaya, 2017.

[6] A. Chengel Yunus and Michael A Boles, Thermodinamics an engineering approach fifth edition, MC Graw Hill, USA, 2006.

[7] Dipak K. Sarkar, Steam power plant cycle chapter 1, Elsevier, Inc., 2020, pp. 1-37.
[8] Black and Veach, Power plant engineering, Springer Science + Business Media, inc. New York, 1996.

[9] Sunit Rout Ivan., Gaikwad Abhishek., Kumar Verma Vinod., \& Tariq Mohammad, Thermal analysis of steam turbine power plants, IOSR Journal of Mechanical and Civil Engineering (IOSR-JMCE), vol. 7, 2013, pp. 29-30. 